Paedagogia Christiana

2/28 (201 I) - ISSN 1505-6872

Katarzyna Lukaszewska*

Toruń

\title{
Postawa ascetyczna a myślenie ekologiczne
}

\author{
Asceza nie jest $[\ldots]$ formą thumienia ludzkiej natury, \\ jak się zazwyczaj uważa. \\ Wręcz przeciwnie, dopiero dzięki niej dochodzi [...] \\ do ujawnienia ukrytej w człowieku harmonii ${ }^{1}$. \\ Humanizm ekologiczny kreuje u człowieka takie cechy, \\ jak: asceza konsumpcji na rzecz bycia, \\ wrażliwość na piękno przyrody, \\ świadomość łączności człowieka z naturą ${ }^{2}$.
}

\section{Asceza pozytywna i jej greckie pochodzenie}

Asceza jest wyzwaniem współczesności, a nazywanie wprost ascetycznymi zachowań pełnych umiarkowania i rozsądku, charakteryzujących się wytrwałością wysiłku i ćwiczeń, powodowanych obecnością uznanych i wybranych wartości, nie jest jedynie usilnym powoływaniem się na określony termin. Etymologia greckiego słowa askesis przekonuje o pozytyw-

* Mgr Katarzyna Łukaszewska - doktorantka w Instytucie Filozofii UMK w Toruniu.

${ }^{1}$ K. J. Pawłowski, Dyskurs i asceza. Kształtowanie człowieczeństwa w kontekście mistyki filozoficznej, Kraków 2007, s. 12.

2 W. Dziabaszewski, Praktyczne sposoby realizowania idei humanizmu ekologicznego oraz formy jego propagowania w społeczeństwie, w: B. Andrzejewski (red.), Humanistyka i ekologia, Poznań 1992, s. 135. 
nym charakterze ascezy wiarygodnej, dostępnej i odpowiadającej możliwościom człowieka. To bowiem głównie swemu greckiemu pochodzeniu asceza zawdzięcza swą autentyczną postać, skupioną przede wszystkim nie na zaprzeczaniu ludzkiej naturze, ale wydobywaniu pewnego szczególnego rysu charakteru działań człowieka w świecie za pomocą regularnych starań i poszukiwań harmonijnego rozwoju w postępowaniu ukierunkowanym na doskonałość tyleż nieosiągalną, co mobilizującą do realnych działań. Należy zaznaczyć więc, że ,pojęcie ascezy w hellenizmie ma charakter $\mathrm{w}$ istocie swej pozytywny, aktywny, dynamiczny i praktyczny. Nie ma ono w zasadzie zabarwienia negatywnego [...]. Moment «ćwiczenia, praktyki, treningu» jest istotny dla uzyskania doskonałości w postawie zajmowanej w dążeniu do uczłowieczenia przez prowadzenie życia ascetycznego"3, w dążeniu do akcentowania naturalnego, dostępnego i wszechstronnego charakteru ascezy.

„Podstawowy w tym temacie czasownik askesis oznacza «ćwiczenie», «praktykowanie», «trening», «tryb życia», a w religijnym: «ascetyzm», «ascezę»"4. Warto podkreślić, że bez względu na zaakcentowanie określonego pola oddziaływania praktyki ascetycznej postawa ta jest w pierwszej kolejności wszechstronną postawą etyczną, sposobem zyskiwania swoistego rysu dojrzałości o określonym sposobie widzenia świata i zadań stawianych człowiekowi. Dlatego też, zgodnie z takim podejściem, asceta to aktywny uczestnik życia, wewnętrznie zobligowany do postępowania w określony, charakterystyczny sposób; sposób będący przede wszystkim trwałym sposobem wyboru wartości. Praktyczny, pozytywny i aktywny charakter greckiego askesis przybliża prawdziwy sens ascezy współczesnemu człowiekowi a także jej uniwersalne odniesienie, także do przestrzeni ekologicznej. Asceza bowiem jest wyborem wartości; w przestrzeni ekologicznej wybiera te, których pojawieniu się sprzyja kontakt człowieka z przyrodą, zaś ascetyczne umiejętności mają za zadanie między innymi poprawę jakości tego kontaktu.

\section{Wysilek ascetyczny jako wybór}

Jeśli przyjmiemy, jak Krzysztof Jan Pawłowski, autor książki Dyskurs $i$ asceza, że „asceza jest wszechstronnym treningiem woli, rozumu i uczuć" - to wysiłek ascetyczny będzie polegał przede wszystkim na wewnętrznym

${ }^{3}$ H. Wójtowicz, Asceza w hellenizmie, w: F. Drączkowski, J. Pałucki (red.), Wczesnochrześcijańska asceza. Zagadnienia wybrane, Lublin 1993, s. 11.

4 Tamże, s. 9-10.

${ }^{5}$ Por. K. J. Pawłowski, dz. cyt., s. 195. 
ćwiczeniu się, doskonaleniu i staraniach, aby przede wszystkim poprzez pracę nad sobą określać jakość i trwałość wyboru wartości. Asceza bowiem to „dobrowolny trud [...] psycho-fizyczny podejmowany przez człowieka, aby osiągnąć jakieś wyższe cele [...] poprzez opanowywanie lub ograniczanie swoich potrzeb, szczególnie emocji, połączony z [...] dyscypliną wobec siebie i z samoopanowaniem". Współczesne zapotrzebowanie na dobrowolne, świadome samoograniczenie łączy się z ujmowaniem ,zjawiska ascezy w kontekście zagrożenia środowiska ludzkiego i w kontekście konsumpcyjnego charakteru kultury naszych czasów"7 i wydaje się, że oba te zagadnienia akcentują „nie tylko indywidualną rację zapotrzebowania na właściwy ascetyzm, lecz także racje społeczne, a nawet globalne"s.

„Prostszy sposób życia zgodny jest z naglącą potrzebą umiaru w eksploatacji nieodnawialnych zasobów i zminimalizowania skutków zanieczyszczenia środowiska"9 i nawet ,z pozoru niewielkie zmiany stylu życia mogą się kumulować, dając pokaźny efekt" ${ }^{10}$. Jednak zmiany te wymagają nie tylko decyzji, ale samodyscypliny, polegającej ,na umiejętności przymuszenia się do racjonalnego zorganizowania wysiłków dla osiągnięcia celu"11. Ascetyczna postawa odniesiona do przestrzeni ekowartości podkreśla fakt, że „w sytuacji ekologicznego zagrożenia współczesny człowiek musi się zdobyć na [...] wyrzeczenie"12, samoograniczenie i wysiłek powodowany uznaniem wyższej wartości. I tak: „myślenie ekologiczne, oparte na akceptacji zdrowia jako wartości wyróżnionej, sprzyja pełnej i skutecznej ochronie środowiska"13, ponieważ to właśnie wartość wyróżniona jest celem, organizatorem praktyki ascetycznej, a nie wysiłek sam dla siebie, bezrefleksyjny. Ekologiczne postępowanie ukierunkowuje na wartość zdrowia, harmonii przyrody i równowagi, jest przede wszystkim postępowaniem w sensie etycznym, postępowaniem ze względu na wartości i ten aspekt ascezy jest kluczowy dla jej współczesnego rozumienia. Asceta jest bowiem w swej

${ }^{6}$ Z. Chlewiński, Asceza z punktu widzenia psychologii, w: W. Słomka (red.), Ascezaodczłowieczenie czy uczłowieczenie, Lublin 1985, s. 26.

7 W. Słomka, Ku prawdzie o ascezie, w: tenże (red.), dz. cyt., s. 12.

8 Tamże, s. 12.

9 D. Elgin, Dobrowolna prostota życia, w: A. H. Badiner (red.), Uważność na targowisku. Globalny rynek i masowa konsumpcja a świadome życie, Warszawa 2004, s. 291.

10 Tamże, s. 293.

11 A. Grzegorczyk, Samodyscyplina i życie intelektualne, w: A. Grzegorczyk, J. Werle, A. Góralski, Trzy eseje z zakresu Liberalizm a samodyscyplina, Warszawa 1996, s. 8.

12 S. Rosik, Obrona środowiska naturalnego jako przejaw ascezy, w: W. Słomka (red.), dz. cyt., s. 82 .

13 Z. Kuderowicz, System wartości a ochrona środowiska, w: B. Andrzejewski (red.), dz. cyt., s. 53 . 
postawie odróżnialny w tym sensie, że poprzez aksjologiczne uzasadnienie realizuje wartości w sposób charakterystyczny, wpisany w plan określonej postawy.

Myślenie ekologiczne to najpierw myślenie o wartościach, kształtowanie w sobie w pierwszej kolejności świadomości aksjologicznej. Od stosunku do świata wartości zależy jakość stosunku do świata ekowartości. Deficyty etycznych umiejętności mają swoje odzwierciedlenie w sposobie odnoszenia się do świata przyrody, zaś zdolność podejmowania ascetycznego wysiłku, wytrwałego podejmowania starań zmierzających do ochrony ekowartości, jest poszukiwaniem równowagi zapobiegającej nadmierności potrzeb, roszczeń i oczekiwań. Jest bowiem w ascezie warunek dla ekologicznych umiejętności kluczowy - to zdolność do samoograniczenia, do osobiście naszkicowanej obowiązkowości, która nie potrzebuje zewnętrznych wymogów, by samemu się do takiej postawy zdyscyplinować. Dlatego świadomie wypracowana asceza ma swoje odniesienie do świata ekowartości, zaś świadomość ekologiczna, określająca „stopień zrozumienia problemów ekologicznych, znajomość zagrożeń związanych z antropopresją oraz wiedzę potrzebną do zapobiegania tym zagrożeniom" 14 - jako element postawy ascetycznej - jest trwałą tendencją do zachowań o określonym charakterze; postawa taka decyduje o tym, że człowiek zyskuje swoisty akcent, specyficzny rys charakteru, którego wyróżniająca cecha polega przede wszystkim na konsekwencji i wytrwałości, wymagających z kolei uporu ćwiczeń i osobistego przekonania o znaczeniu podejmowania dobrowolnego wysiłku w życiu człowieka.

Ascetyczny wysiłek nie ma jednak charakteru autotelicznego, a raczej wiąże się ze świadomością aksjologiczną, która do wizji perfekcji w ludzkim wymiarze przekonuje na drodze dążenia i starań raczej niż osiągalności. Możliwy jest bowiem taki sposób życia, którego afirmacja „ściśle związana jest z wartościowaniem, które wymaga przyjęcia określonych kryteriów etycznych i motywacji ascetycznej”" ${ }^{15}$. Obecność wartości jest w tym sensie mobilizującą, doskonalącą, uzasadniającą ascetyczny trud.

\section{Postawa ascetyczna a wartości świata przyrody. Związek etyki z ekologią}

Asceza w przestrzeni ekologii to przede wszystkim odniesienie do wartości. Jest bowiem w stosunku do wartości ekologicznych coś elementarne-

\footnotetext{
${ }^{14}$ W. Dziabaszewski, dz. cyt., s. 135.

${ }^{15}$ S. Rosik, dz. cyt., s. 79.
} 
go, podstawowego, kluczowego. Stefan Pikus, pisząc o kulturze moralnej jednostki, zaznaczył, że

dla współczesnego człowieka wysokość kultury moralnej zależeć powinna nie tylko od przestrzegania tradycyjnych norm moralnych, lecz także (a może głównie) - od realizacji nowych norm elementarnych określających jego stosunek do przyrody. W żadnym wypadku nie można nazwać człowiekiem o wysokiej kulturze moralnej takiej jednostki, która realizuje tradycyjny w kulturze europejskiej prymitywny wzorzec stosunku do przyrody oparty na filozoficznym założeniu: «człowiek panem przyrody». Innymi słowy: człowiek dewastujący w ten sposób przyrodę, choćby respektował większość tradycyjnych norm moralnych, nie jest człowiekiem o wysokiej kulturze moralnej, gdyż łamie te elementarne normy moralne, których przestrzeganie jest warunkiem naszego istnienia i rozwoju ${ }^{16}$.

To nie naszkicowany perfekcjonistyczną usilnością abstrakcyjny plan, ale kluczowość i elementarność odwołania się do obiektywności wartości stanowią tu podstawę. Wartości, które zobowiązują, ukierunkowują i stawiają wymagania.

Jak słusznie zauważa Jerzy W. Gałkowski, ,[...] żadne nasze oddziaływanie na przyrodę nie jest i nie może być moralnie neutralne. Kształtujemy bowiem nie tylko świat rzeczy, ale przezeń zarazem i przede wszystkim odnosimy się do drugiego człowieka [...]. Ochrona przyrody więc [...] jest to jedno z podstawowych wymagań stawianych człowiekowi w imię człowieka"17. Asceza określa te wymagania za pomocą odniesienia do wartości, pośród których te szczególnie związane ze światem przyrody są po prostu integralną częścią składową, nierozłączającą myślenia ekologicznego z aksjologicznym. Działanie w obliczu obiektywnie ważnych wartości wspiera sens płynący przede wszystkim z wymagań przestrzeni aksjologicznej.

Potrzebę utożsamiania związków etyki i ekologii uzasadnia słuszne przekonanie, że zachowanie się człowieka wobec przyrody (korzystne lub szkodliwe dla niej) w znacznym stopniu zależy od poziomu jego świadomości, wyznaczonego systemu wartości, wzorów kulturowych, wrażliwości, charakteru wychowania. Jeśli tak rzeczywiście jest [...] to nie można skutecznie chronić środowiska przyrodniczego ignorując znaczenie wartości, zasad i wychowania

${ }^{16}$ S. Pikus, Kultura moralna jednostki, w: J. Dębowski, E. J. Pałysa (red.), Człowiek $i$ świat przyrody - edukacja ekologiczna, Olsztyn-Warszawa 1994, s. 53.

17 J. W. Gałkowski, Człowiek - przyroda - wartości, w: L. Pawłowski, S. Zięba (red.), Humanizm ekologiczny. Jakiej filozofi potrzebuje ekologia. Ochrona przyrody a ochrona człowieka, Lublin 1992, s. 49. 
moralnego, gdyż etyka może pobudzać i wzmacniać poczynania odnoszące się do praktycznych kontaktów człowieka z otoczeniem, z kolei niedostatek wymiaru etycznego negatywnie odbija się na kontaktach człowieka ze swym naturalnym otoczeniem ${ }^{18}$.

Dlatego też można stwierdzić, że kondycja aksjologiczna będzie się przekładać na sferę ekologiczną, a stosunek do ekowartości z kolei wiele mówi o stosunku człowieka do wartości w ogóle. Nie da się bowiem odseparować świadomości ekologicznej od myślenia o wartościach; jest ona elementarnym składnikiem świadomego uczestniczenia w urzeczywistnianiu określonych wartości, co łączy się z zobowiązaniem wypływającym z uznania ich znaczenia.

W postawie ascetycznej stosunek do wartości służy do wyjaśnienia znaczenia myślenia ekologicznego, które z kolei można odczytywać w podobny sposób, jak i dążeniowy, rozwojowy charakter ascezy. Zwłaszcza że, jak zauważa Helena Sęk, ,najważniejszym elementem myślenia ekologicznego jest fakt, [...] iż stan równowagi w podejściu ekologicznym jest traktowany jako fakt teoretyczny - sytuacja, która jest raczej poszukiwana niż po prostu dana, czy istniejąca; [...] ekolog pyta najczęściej o to, co należy uczynić, aby ów stan równowagi osiągnąć, a przynajmniej zbliżyć się do niego"19. W podobny sposób kształtuje się postawa ascety; askesis to ćwiczenie, które zbliża do perfekcjonistycznie naszkicowanego celu, niemniej jednak takie teoretycznie pojmowanie celu ascezy ma bardzo znaczące konsekwencje praktyczne - umożliwia mianowicie ochronę wiarygodności i autentyczności ascetycznych ćwiczeń. Jeżeli asceta to człowiek, który ćwiczy się niejako w swoistym ,czytaniu” wartości, w ich trwałym rozpoznawaniu, tak by to od siebie rozpoczynać troskę aksjologiczną i z siebie wyprowadzać potrzebę zmiany, doskonalenia, dążenia do doskonałości - to asceza jako samoograniczenie i samodoskonalenie nakreśla plan zmian, jakie można wnieść w świat tylko za pośrednictwem samodyscypliny konkretnego człowieka, ponieważ poprzez poprawę własnych predyspozycji człowiek może zmienić tę część, na którą rzeczywiście ma największy wpływ. Dlatego ascetyczne umiejętności są próbą uzdolnienia siebie samego do polepszania sytuacji wartości w świecie.

${ }_{18}$ W. Tyburski, Etyka i ekologia, Torun 1995, s. 7.

${ }^{19}$ H. Sęk, cyt. za: K. Laskowski, Cztery sposoby pojmowania ekologii, czyli o przestankach ekofilozofii, w: Z. Hull, W. Tulibacki (red.), Człowiek wobec świata, Olsztyn 1996, s. 100 . 


\section{Asceza roszczeń i jej ekologiczne znaczenie}

Kwestię ekowartości stawiać można bardzo jednoznacznie i rygorystycznie, jak czyni to chociażby Henryk Skolimowski, który twierdzi wprost, że „dziś myśleć dobrze [...] to myśleć ekologicznie. Dotyczy to myślenia technicznego, politycznego, a nawet religijnego"20. Nie da się dziś, zgodnie z takim ujęciem, w ramy słusznego postępowania wpisywać zachowań pozbawionych odniesień do świata ekowartości. Takie podejście zwraca również uwagę na kierunek wypływania zagrożeń (czyli od człowieka w świat) i obliguje do rozpoczynania wszelkich aspiracji naprawczych także poprzez odniesienie do człowieka. Zwłaszcza że, jak podkreśla Julian Aleksandrowicz, autor znanej książki Sumienie ekologiczne, „współczesny kryzys ekologiczny wykazuje niepokojące sprzężenie z narastającym zanikiem samoświadomości etycznej, dotyczącej związków człowieka z przyrodą" ${ }^{21}$. Przestrzeń ekowartości cierpi na skutek znikomej świadomości roli i znaczenia wysiłków o charakterze wyrzeczeniowym, samodyscyplinującym, ascetycznym, których wymiar wykracza znacznie poza sferę refleksji teoretycznej i deklaratywnej aprobaty. Asceta współczesny to sprawny praktyk, dlatego ekologiczne aspekty jego aktywności są tak naprawdę przejawami przemyślenia, zrozumienia i praktycznego ćwiczenia tej zobowiązującej względem wartości postawy. Można więc powiedzieć, że w człowieku zarówno „tkwią główne przyczyny współczesnego kryzysu ekologicznego"22, jak i szansa na poprawę istniejącej sytuacji na drodze dobrowolnego umiaru i ascetycznej samodyscypliny. „Bez zmian ludzkich nawyków [...], bez głębokiej przemiany naszej osobowości wszelkie przedsięwzięcia ochraniające życie na Ziemi będą jedynie powierzchowne i krótkotrwałe"23.

Asceza, która kształtuje wewnętrzne umiejętności, usprawnia sposób odnoszenia się do rzeczywistości, w tym także do zjawisk ekologicznych, w sposób akcentujący postawę człowieka trwale przystosowanego do decyzji o charakterze dobrowolnego wyrzeczenia i świadomej, celowej rezygnacji. Bowiem „w postawach i sposobach zachowania się ludzi nie nastąpią zmiany dopóty, dopóki większość członków danej społeczności dobrowolnie

${ }^{20}$ Cytuję za: W. Tyburski, Pojednać się z Ziemia. W kręgu zagadnień humanizmu ekologicznego, Toruń 1993, s. 37.

${ }^{21}$ Cytuję za: W. Tyburski, Pojednać się, s. 83; por. też: J. Aleksandrowicz, Człowiek i jego łańcuch troficzny, w: M. Szyszkowska (red.), Wokót istnienia człowieka, Warszawa 1991, s. 13.

${ }^{22}$ G. Francuz, Uwagi dotyczace filozoficznych założeń edukacji ekologicznej, w: J. Dębowski, E. J. Pałysa (red.), dz. cyt., s. 107.

${ }^{23}$ Tamże, s. 107. 
i świadomie nie dostrzeże wyższych wartości środowiska i nie przyswoi sobie na tyle pozytywnego stosunku do otoczenia, aby zmusić się do samodyscypliny i samoograniczenia (wręcz ascezy)" ${ }^{\prime 24}$. Stąd też zmiana w podejściu do świata przyrody musi być zmianą, która urzeczywistnia się ze względu na umiejętność ascezy dobrowolnej i świadomie wybranej, zdolnej wypracować trwałą tendencję do postępowania w określony wartościami sposób.

\section{Asceta - ekolog}

Asceta ćwiczy się w umiarze i poszukiwaniu równowagi, zaczynając od siebie, a ponieważ „to w człowieku właśnie należy poszukiwać sposobów przezwyciężania kryzysu ekologicznego" ${ }^{25}$, to wobec tego od kształtowania własnej postawy należałoby także zacząć wszelką zmianę. To poprzez osobistą wytrwałość wnosimy zmianę w świat ${ }^{26}$, a w kontekście zagrożeń środowiska naturalnego osobista asceza jest postawą człowieka, który wybierając wartości - czyni wewnętrzne zobowiązania, które ten wybór potwierdzają i podtrzymują określonym działaniem. Obojętny czy lekceważący stosunek wobec ekowartości tak wiele mówi więc o podejściu do aksjologicznego świata, ponieważ to „od kultury moralnej jednostki zależy jej stosunek do środowiska, w którym żyje" ${ }^{27}$. Asceta jest ekologiem ponieważ ekowartości, do których „należą: życie, zdrowie, odpowiedzialność, powściągliwość, umiar, solidarność, praca, piękno, harmonia, kontemplacja, współczucie [...] przynależne są osobie ludzkiej, a ich ekologiczny aspekt ujawnia się w kontaktach człowieka z przyrodą. Pogwałcanie owych wartości nieodmiennie prowadzi do degradacji człowieka i świata przyrody. Innymi słowy: kryzys ekologiczny jest również kryzysem wartości" ${ }^{\prime 28}$. Z wyborem wartości łączy się bowiem zdolność do wzięcia na siebie odpowiedzialności zarówno w kwestii decyzji, jak i zaniechania określonych zachowań, tak wyboru, jak i rezygnacji.

${ }^{24}$ E. Trzaskowska, O potrzebie i formach edukacji ekologicznej, w: L. Pawłowski, S. Zięba (red.), dz. cyt., s. 97.

25 J. Filipowski, Człowiek i środowisko przyrodnicze, w: J. Dębowski (red.), Człowiek i środowisko, prace I Olsztyńskiego Sympozjum ekologicznego - Olsztyn 5-6 maja 1994, Olsztyn 1995, s. 247.

${ }^{26}$ „Dobro w świecie odkrywamy w miarę jak sami stajemy się lepsi; doskonalenie się etyczne jest nieodzownym warunkiem przebicia się do świata wartościowego". Por. H. Elzenberg, Kłopot z istnieniem. Aforyzmy w porzadku czasu, Toruń 2002, s. 294.

27 S. Pikus, dz. cyt., s. 54.

${ }^{28}$ W. Tyburski, Pojednać się, s. 97. 
„Postawa proekologiczna opiera się na określonej hierarchii wartości, które człowiek respektuje i pragnie urzeczywistniać" ${ }^{29}$. Asceza zaś jest sposobem realizowania własnych postanowień, jest ćwiczeniem się w pracy nad sobą. ,Niektórzy autorzy mówią o powściągliwości jako wartości ekologicznej, która powinna charakteryzować odpowiedzialne działania wobec przyrody" "30; chciałabym, aby o ascezie mówiło się w kontekście myślenia ekologicznego jako o sposobie życia, który w klimacie etyki umiaru dobrowolnie podjęty wysiłek, wytrwałość i wiarygodność traktuje jako element współczesnej troski o własną jakość bycia w świecie.

\section{Ascetic Attitude and Ecological Thinking \\ (Summary)}

Asceticism is founded on the etymology of Greek word askesis, which means 'to exercise', 'to practice', 'to give a shape' and this meaning is connected with activity and practical skills. The asceticism is a way of thinking, a way of living and a way of choice. Affirmative elements of asceticism like voluntary self-denial, simplicity, and moderation are a challenge to the world of today and present an authentic human picture of ascetic life. Ecological thinking is a part of this life, a part of moral mature and shows how our real relations with objective values look like.

\footnotetext{
29 Tamże, s. 93.

30 Z. Kuderowicz, dz. cyt., s. 54.
} 